\title{
Association of risk factors of carcinoma cervix with abnormal pap results among women attending a tertiary care hospital of jharkhand: A cross sectional study
}

\author{
Abhishek Kumar', Swati Shikha², Vivek Kashyap ${ }^{3}$ \\ ${ }_{1,2}$ Assistant Professor, Department of Community Medicine, Narayan Medical College and Hospital, Sasaram, \\ ${ }^{3}$ Professor and Head, Department of Preventive and Social Medicine, Rajendra Institute of Medical Sciences, Ranchi
}

Background: Cervical cancer has become a vital cause of cancer mortality among women worldwide. It is the fifth most common cancer overall and second most common cancer among women worldwide. Aims and Objectives: To assess the frequency of established risk factors of cervical cancer among study subjects and to find out the association between socio demographic variables and risk factors with results of pap smear test. Materials and Methods: Hospital based cross sectional study was conducted in Pathology department of Rajendra Institute of medical sciences, Ranchi for 3 months (September - November 2017) on total of 106 women who gave consent. Results: All the women ( $n=106)$ were married, 68 out of $106(64.2 \%)$ were Hindus, 57 out of $106(53.8 \%)$ were non Tribals $60.4 \%$ were from urban area and most of them 62 out of $106(58.49 \%)$ were housewives. Amongst risk factors, 69 out of 106(65.09\%) had their first sexual intercourse before 18 years of age, only 11 out of $106(10.4 \%)$ were addicted to smoking and 42 out of $106(39.62 \%)$ had past history of STIs. Educational status and Socio economic status was found to be significantly associated with abnormal pap smear results with $p$ value $<0.05$. Conclusion: Most of the women were from non tribal ethnicity and urban background and illiterate with the mean age of $37.9 \pm 10.56$ years. Educational status and Socio economic status were significantly associated with abnormal Pap results

Key words: Risk factors; Carcinoma; Cervix; Pap test

\section{Access this article online}

Website:

http://nepjol.info/index.php/AJMS DOI: 10.3126/ajms.v12i8.36343 E-ISSN: 2091-0576 P-ISSN: $2467-9100$

Copyright (c) 2021 Asian Journal of Medical Sciences

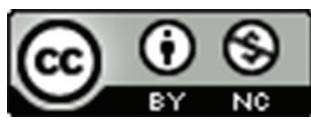

This work is licensed under a Creative Commons Attribution-NonCommercial 4.0 International License.

\section{INTRODUCTION}

Cervical carcinoma is one of the most common and dreaded diseases of women, and in India, it accounts for one fourth of total cervical cancer cases occurring globally. ${ }^{1}$ It is one of the principal causes of cancer mortality among women globally, ${ }^{2}$ amounting to $17 \%$ of all female cancer deaths between $30-69$ years. ${ }^{3}$ Despite being most preventable cancer, it is still the world's second leading cancer killer of women. ${ }^{4}$ India accounts for about $25 \%$ of cervical cancer cases reported from the world. Every year in India, 122,844 women are being diagnosed with cervical cancer while 67,477 die from the disease. ${ }^{5}$ According to National Institute of Cancer Prevention and Research, one woman dies of cervical cancer every 8 minutes in India. ${ }^{6}$ India also has the highest age-standardized incidence of cervical cancer in South Asia at 22, compared to 19.2 in Bangladesh, 13 in Sri Lanka, and 2.8 in Iran. India has a population of 469.1 million women aged $\geq 15$ years, all of them being at the risk of developing cancer. ${ }^{7}$ The established risk factors of cervical cancer are increasing age, lower socioeconomic status, non-maintenance of personal hygiene, lack of literacy, multiple sexual partners, tender age at marriage and first child birth, high parity and long-term use of hormonal contraceptive. ${ }^{8}$ Other factors which may 
account to increased risk are co-infection with Chlamydia trachomatis, HIV and Herpes simplex virus type-2, immunosuppression, and certain dietary deficiencies such as deficiency of vitamin A, C, E and selenium. ${ }^{9}{ }^{10}$ Human Papilloma Virus (HPV) is though a necessary cause but not sufficient cause of cervical cancer. In India, about $75 \%$ of population resides in rural area where along with factors like multiparty, early age at marriage, poor genital hygiene, other factor like negligence by patient to initial symptoms like leucorrhoea, post coital bleeding due to unawareness, illiteracy and lack of adequate screening facilities prevail which increases incidence among Indian women. ${ }^{11}$ The usual 10-20 years of natural history of progression from mild dysplasia to carcinoma cervix makes this cancer as relatively early preventable disease. Incidence among women having parity $\geq 3$ are more. ${ }^{12}$ Screening for this cancer is effective, feasible and affordable way for its early detection. ${ }^{13}$ Cytological screening technique serves as a simple and cost effective way to detect these dysplastic lesions at earliest stage. ${ }^{14}$ Pap smear test is the most commonly used test and has been recognized as the first line of investigation in screening of cervical cancer. It is a simple, safe, economical and reliable technique. ${ }^{13}$ Studies on cervical cancer are sparse from Jharkhand and since this cancer is emerging as a deadly disease so the present study was conducted with the objectives to assess the frequency of established risk factors of cervical cancer among study subjects and to find out the association between socio demographic variables and risk factors with results of Pap smear test.

\section{MATERIALS AND METHODS}

This was a hospital based cross sectional study conducted in the department of Pathology, Rajendra Institute of Medical Sciences, Ranchi among women aged above 21 years attending the Pap test laboratory of pathology department between $11 \mathrm{am}$ to $4 \mathrm{pm}$ on all working days of the week for a duration of 3 months (September - November 2017) and giving consent for study. Severely ill patients were excluded from the study. Period of data collection was 1 month during which a total of 106 women attended pathology department and gave consent. Hence the sample size was 106 chosen by total convenient sampling. Subjects were interviewed at the time they came to collect their reports so that detailed interview and the report results could be recorded together. Data was collected using a semi-structured pretested questionnaire comprising of questions on socio demographic characteristics, risk factors and final pap test results. Templates were generated on MS - Excel sheet and data analysis was done using SPSS version 20.0 software. The statistical tests used were descriptive statistics and
Pearson's Chi-square test and $\mathrm{P}$ value of less than 0.05 was considered significant. Ethical clearance was obtained from institutional ethics committee prior to start of the study. Informed written consent was taken from the study subjects after explaining the purpose of the study.

\section{RESULTS}

Total of 106 women participated in the present study out of which $57(53.8 \%)$ were non Tribals, 64 out of $106(60.4 \%)$ resided in urban areas and most of them 68 out of 106 (64.2\%) were Hindus, 42 out of 106 (39.6\%) were illiterate, all of them were married and none belonged to upper class of socio economic status according to modified BG Prasad classification of January 2017. Table 1 shows the socio demographic characteristics of the study participants. The distribution of risk factors in terms of mean and standard deviation of age is shown in Table 2. The mean age of the study participants was $37.9 \pm 10.56$ years and age at $1^{\text {st }}$ sexual intercourse and $1^{\text {st }}$ child birth was $18.27 \pm 2.8$ years and $19.69 \pm 2.17$ years respectively. Table 3 shows the frequency distribution of various risk factors. It was found that history of smoking was present in 11 out of $106(10.4 \%)$ and majority 90 out of $106(84.9 \%)$ never used any oral contraceptive pills. Total number of women diagnosed with inflammatory

\begin{tabular}{|c|c|c|c|c|}
\hline S.No. & Variable & & Frequency & Percentage \\
\hline \multirow[t]{2}{*}{1} & Ethnicity & Tribal & 49 & $46.2 \%$ \\
\hline & & Non tribal & 57 & $53.8 \%$ \\
\hline \multirow[t]{2}{*}{2} & Residence & Rural & 42 & $39.6 \%$ \\
\hline & & Urban & 64 & $60.4 \%$ \\
\hline \multirow[t]{4}{*}{3} & Religion & Hindu & 68 & $64.2 \%$ \\
\hline & & Muslim & 17 & $16 \%$ \\
\hline & & Saran & 08 & $7.5 \%$ \\
\hline & & Christian & 13 & $12.3 \%$ \\
\hline \multirow[t]{5}{*}{4} & Education & Illiterate & 42 & $39.6 \%$ \\
\hline & & Primary & 30 & $28.3 \%$ \\
\hline & & Secondary & 20 & $18.9 \%$ \\
\hline & & $\begin{array}{l}\text { Senior- } \\
\text { secondary }\end{array}$ & 11 & $10.4 \%$ \\
\hline & & Graduate & 03 & $2.8 \%$ \\
\hline \multirow[t]{4}{*}{5} & Occupation & Student & 13 & $12.26 \%$ \\
\hline & & Housewife & 62 & $58.49 \%$ \\
\hline & & $\begin{array}{l}\text { Dailywage } \\
\text { labour }\end{array}$ & 24 & $22.64 \%$ \\
\hline & & $\begin{array}{l}\text { Service } \\
\text { class }\end{array}$ & 07 & $6.6 \%$ \\
\hline \multirow[t]{2}{*}{6} & Marital & Married & 106 & $100 \%$ \\
\hline & status & Un married & 0 & $0 \%$ \\
\hline \multirow[t]{5}{*}{7} & Socio & Class 1 & 00 & $0 \%$ \\
\hline & economic & Class2 & 12 & $11.3 \%$ \\
\hline & status & Class 3 & 28 & $26.4 \%$ \\
\hline & & Class 4 & 34 & $32.1 \%$ \\
\hline & & Class 5 & 32 & $30.2 \%$ \\
\hline
\end{tabular}

Asian Journal of Medical Sciences | Aug 2021 | Vol 12 | Issue 8 
lesions are shown in Figure 1. Table 4 and Table 5 shows the association of socio demographic variables with the Pap test results it is seen that education status and socio economic status is significantly association with abnormal pap smear result findings with $\mathrm{p}$ value of $<0.05$. Table 6 shows the association of established risk factors with abnormal pap smear results. It is seen that none of the risk factors are significantly associated with Pap smear test results.

\section{DISCUSSION}

Cervical cancer is the fourth most frequent cancer in women with about 5,70,000 new cases diagnosed in 2018,

\begin{tabular}{llcc}
\multicolumn{3}{l}{ Table 2: Risk Factors } \\
\hline S. No. & Variables & $\begin{array}{c}\text { Mean } \\
\text { (years) }\end{array}$ & $\begin{array}{c}\text { Standard } \\
\text { Deviation }\end{array}$ \\
\hline 1. & Age of the subject & 37.9 & \pm 10.56 \\
2. & Age at Marriage & 18.09 & \pm 1.99 \\
3. & Age at $1^{\text {st }}$ sexual intercourse & 18.27 & \pm 2.8 \\
4. & Age at $1^{\text {st }}$ child birth & 19.69 & \pm 2.17 \\
\hline
\end{tabular}

representing about $6.6 \%$ of all female cancers. During 2018, about 311365 women died of cervical cancer which accounts for $3.2 \%$ of all deaths due to cancer in women. About $90 \%$ of these deaths occur in low and middle income countries. ${ }^{16}$ The present study was conducted to find out the association of established risk factors of cervical cancer with its occurrence and it was found that the mean

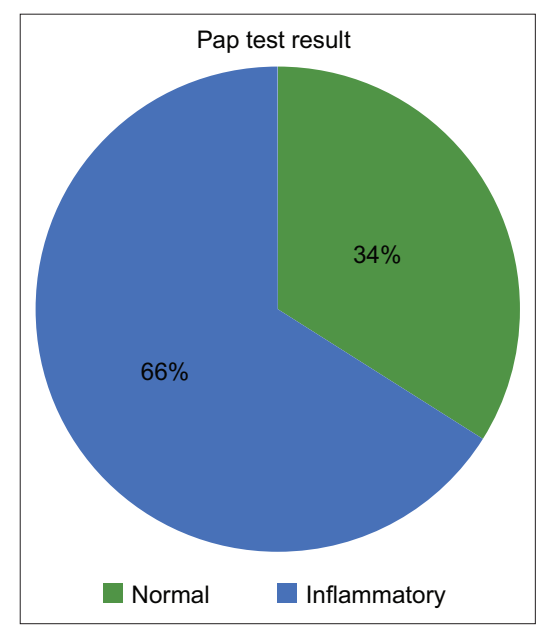

Figure 1: Findings of pap smear test $(n=106)$

\section{Table 3: Frequency of established risk factors $(n=106)$}

\begin{tabular}{|c|c|c|c|c|}
\hline S. No. & Established risk factors & & Frequency & Percentage \\
\hline \multirow[t]{2}{*}{1} & Maintenance of menstrual hygiene & Adequate & 81 & $76.42 \%$ \\
\hline & & Poor & 25 & $23.58 \%$ \\
\hline \multirow[t]{2}{*}{2} & Age at $1^{\text {st }}$ sexual intercourse & $\leq 18$ years & 69 & $65.09 \%$ \\
\hline & & $>19$ years & 37 & $34.91 \%$ \\
\hline \multirow[t]{2}{*}{3} & History of smoking & Present & 11 & $10.4 \%$ \\
\hline & & Absent & 95 & $89.6 \%$ \\
\hline 4 & Past history of STIs & Yes & 42 & $39.62 \%$ \\
\hline \multirow[t]{3}{*}{5} & Use of OCPS & Never consumed & 90 & $84.9 \%$ \\
\hline & & Taken occasionally & 13 & $12.3 \%$ \\
\hline & & Taken regularly for $>8$ years & 03 & $2.8 \%$ \\
\hline
\end{tabular}

\section{Table 4: Association of socio demographic characteristics with pap test results $(\mathrm{n}=106)$}

\begin{tabular}{|c|c|c|c|c|c|}
\hline \multirow[t]{2}{*}{ s. no } & \multirow[t]{2}{*}{ Variables } & & \multicolumn{2}{|c|}{ Pap smear results } & \multirow[t]{2}{*}{$P$ value } \\
\hline & & & Normal & inflammatory & \\
\hline \multirow[t]{2}{*}{1} & Ethnicity & Tribal & $\begin{array}{c}16 \\
(32.7 \%)\end{array}$ & $\begin{array}{c}33 \\
(67.3 \%)\end{array}$ & 0.792 \\
\hline & & Non tribal & $\begin{array}{c}20 \\
(35.1 \%)\end{array}$ & $\begin{array}{c}37 \\
(64.9 \%)\end{array}$ & \\
\hline \multirow[t]{2}{*}{2} & Residence & Rural & $\begin{array}{c}18 \\
(42.9 \%)\end{array}$ & $\begin{array}{c}24 \\
(57.1 \%)\end{array}$ & 0.117 \\
\hline & & Urban & $\begin{array}{c}18 \\
(28.1 \%)\end{array}$ & $\begin{array}{c}46 \\
(71.9 \%)\end{array}$ & \\
\hline \multirow[t]{3}{*}{3} & Education & Illiterate & $\begin{array}{c}08 \\
(19.0 \%)\end{array}$ & $\begin{array}{c}34 \\
(81.0 \%)\end{array}$ & $<0.001$ \\
\hline & & Primary & $\begin{array}{c}15 \\
(50 \%)\end{array}$ & $\begin{array}{c}15 \\
(50 \%)\end{array}$ & \\
\hline & & Secondary & $\begin{array}{c}04 \\
(20 \%)\end{array}$ & $\begin{array}{c}16 \\
(80 \%)\end{array}$ & \\
\hline
\end{tabular}




\begin{tabular}{|c|c|c|c|}
\hline \multirow[t]{2}{*}{ SES } & \multicolumn{2}{|c|}{ Pap smear results } & \multirow[t]{2}{*}{$P$ value } \\
\hline & Normal & Inflammatory & \\
\hline Upper middle & $\begin{array}{c}08 \\
(66.7 \%)\end{array}$ & $\begin{array}{c}04 \\
(33.3 \%)\end{array}$ & 0.015 \\
\hline Middle & $\begin{array}{c}09 \\
(32.1 \%)\end{array}$ & $\begin{array}{c}19 \\
(67.9 \%)\end{array}$ & \\
\hline Lower middle & $\begin{array}{c}06 \\
(17.6 \%)\end{array}$ & $\begin{array}{c}28 \\
(82.4 \%)\end{array}$ & \\
\hline Lower & $\begin{array}{c}13 \\
(40.6 \%)\end{array}$ & $\begin{array}{c}19 \\
(59.4 \%)\end{array}$ & \\
\hline Total & $\begin{array}{c}36 \\
(34 \%)\end{array}$ & $\begin{array}{c}70 \\
(66 \%)\end{array}$ & \\
\hline
\end{tabular}

\begin{tabular}{|c|c|c|c|c|}
\hline \multirow{2}{*}{$\begin{array}{l}\text { S. } \\
\text { No. }\end{array}$} & \multirow[t]{2}{*}{ Risk factors } & \multicolumn{2}{|c|}{ Pap smear results } & \multirow[t]{2}{*}{$P$ value } \\
\hline & & Normal & Inflammatory & \\
\hline 1 & $\begin{array}{l}\text { OCP consumption } \\
\text { Never } \\
\text { consumed } \\
\text { Taken } \\
\text { occasionally } \\
\text { Taken regularly } \\
\text { for }>8 \text { years }\end{array}$ & $\begin{array}{c}30 \\
(33.3 \%) \\
05 \\
(38.5 \%) \\
01 \\
(33.3 \%)\end{array}$ & $\begin{array}{c}60 \\
(66.7 \%) \\
08 \\
(61.5 \%) \\
02 \\
(66.7 \%)\end{array}$ & 0.935 \\
\hline 2 & $\begin{array}{l}\text { Smoking habit } \\
\text { No } \\
\text { Yes }\end{array}$ & $\begin{array}{c}32 \\
(33.7 \%) \\
04 \\
(36.4 \%)\end{array}$ & $\begin{array}{c}63 \\
(66.3 \%) \\
07 \\
(63.6 \%)\end{array}$ & 0.859 \\
\hline
\end{tabular}

age of study participants was $37.9 \pm 10.56$ years and age at $1^{\text {st }}$ sexual intercourse and $1^{\text {st }}$ child birth were $18.27 \pm$ 2.8 years and $19.69 \pm 2.17$ years respectively whereas in a study done by Vijay Manohar Bhagat et al., ${ }^{15}$ mean age was 37.54 years which is similar to the findings of this study. Cervical cancer most commonly affects women in their most productive age group $25-45$ years. ${ }^{16}$

In the present study it was found that illiteracy is significantly associated with abnormal pap smear findings. This is important as illiteracy will lead to poor genital and menstrual hygiene and poor awareness about the symptoms of inflammatory lesions. A study done by Thakur et al., in Himachal Pradesh ${ }^{2}$ also have similar findings where illiteracy was documented as a cause for early age at marriage, high parity, poor dietary intake, poor utilization of health services in addition to factors mentioned in the present study.

Socioeconomic status has a directly proportional role in practices of healthy behaviour such as practice of proper genital hygiene, level of knowledge and understanding and also the acceptability of services by government to prevent cervical cancer. In the present study it was found that poor socio economic status was significantly associated with the presence of inflammatory pap smear findings with $\mathrm{p}$ value $<0.05$.

\section{CONCLUSION}

Cancer of the uterine cervix is one of the preventable cancers among women. Prevention can be by early screening and awareness generation among women. Among the established risk factors, educational status and the socio economic status of women were found to be significantly associated with presence of inflammatory lesions.

\section{ACKNOWLEDGEMENT}

We thank the faculty members and staffs of department of Preventive and Social Medicine and department of Pathology for allowing us carry out this study and also support us. We also thank the study subjects who gave consent and participated in the study.

\section{REFERENCES}

1. Srivastava AN, Misra JS, Srivastava S, Das BC and Gupta S. Cervical cancer screening in rural India: Status and current concepts. Indian J Med Res. 2018; 148:687-696.

https://doi.org/10.4103/ijmr.IJMR_5_17

2. Thakur A, Gupta B, Gupta A and Chauhan R. Risk factors for cancer cervix among rural women of a hilly state: A case-control study. Indian J Public Health. 2015; 59:45-48.

https://doi.org/10.4103/0019-557X.152862

3. Bobdey S, Sathwara J, Jain A and Balasubramaniam G. Burden of Cervical Cancer and Role of Screening in India. Indian J Med Paediatr Oncol. 2016; 37(4): 278-285.

https://doi.org/10.4103/0971-5851.195751

4. AM Kadri. IAPSM's Textbook of Community Medicine. $1^{\text {st }}$ edition. Kundli, Haryana: Jaypee Brothers Medical Publishers (P) Ltd; 2019. Pg 630.

5. World Health Organisation. GLOBOCAN 2012: Cervical Cancer Estimated Incidence, Mortality and Prevalence Worldwide in 2012. GLOBOCAN 2012. Available at http://globocan.iarc.fr/ Pages/fact_sheets_cancer.aspx. (Accessed on 25/03/2021)

6. Sathiyalatha $S$, Hemavathy $V$ and Vijayalakshmi R. Cervical cancer kills one Indian woman every 7 minutes. Int J Innov Res Dev. 2015; 4:132-134.

7. ICO HPV Information Centre. Human Papillomavirus and Related Diseases Report: INDIA. Available at: http://www.hpvcentre.net/ statistics/reports/IND.pdf (Accessed on 25/03/2021)

8. Sreedevi A, Javed $R$ and Dinesh A. Epidemiology of cervical cancer with special focus on India. Int J Womens Health. 2015; 7:405-414

https://doi.org/10.2147//JWH.S50001

9. World Health Organization. Comprehensive cervical cancer control: A guide to essential practice. Geneva: WHO; 2006. p.32-49. (Accessed on 25/03/2021)

10. Slattery ML, Abbott TM, Overall JC, Robison LM, French TK, Jolles $C$, et al. Dietary Vitamin A, C and $E$ and selenium as Risk Factors for Cervical Cancer. 1990; 1(1):8-15. https://doi.org/10.1097/00001648-199001000-00004

11. Mhaske M, Jawadekar SJ and Saundale SG. Study of association of some risk factors and cervical dysplasia/cancer among rural women National Journal of Community Medicine. 
2011 ; 2(2): 209-212.

12. Nelson SB, Viswanathan NK, Nisha A, Jenifer and Priyanka B. A Cross-sectional Study on cervical cancer and its prevention among Women of Age group 25-50 years in a rural area of South Tamil Nadu, India. Int J Community Med Public Health. 2018; 5(6):2536-2541.

https://doi.org/10.18203/2394-6040.ijcmph20182191

13. Howkins and Bourne: Gynecological diagnosis. Shaw's textbook of gynaecology, $13^{\text {th }}$ edition. Churchill Livingstone, New Delhi
1999;76-77.

14. Kalyani $R$, Sharief $N$ and Shariff $S$. A Study of Pap Smear in a Tertiary Hospital in South India. J Cancer Biol Res.2016; 4(3): 1084.

15. Khamankar ST, Belekar V, Bhagat VM and Baviskar SR. cervical cancer screening: risk factors for cervical neoplasia among rural women of Nanded Maharashtra, Innovative Journal of Medical and Health Science.2014; 312-316.

16. K Park. Parks textbook of preventive and social medicine. 25 ${ }^{\text {th }}$ edition. Jabalpur: Bhanot Publishers; 2019

\footnotetext{
Authors contribution:

Work attributed to:

Rajendra Institute of Medical Sciences, Ranchi. Jharkhand

Orcid ID:

Dr Abhishek Kumar- (i) https://orcid.org/0000-0003-2681-3643

Dr Swati Shikha- https://orcid.org/0000-0001-8522-692X
}

AK: Concept of study, draft of study proposal and literature review, statistical analysis and interpretation of results. SS: Literature review, preparation of questionnaire, planning analysis, manuscript preparation. VK: Planning analysis, Interpretation of results and review of manuscript.

Source of Funding: None, Conflict of interest: None. 